\title{
PEMBERDAYAAN PADA IBU PKK RT. 03 RW. O1 DESA PAMOLOKAN TENTANG PENTINGNYA IMUNISASI DASAR LENGKAP PADA ANAK BALITA
}

\author{
Zakiyah Yasin $^{1)}$, Nailiy Huzaimah ${ }^{2)}$, Iva Gamar Dian Pratiwi ${ }^{3)}$ \\ ${ }^{1,2)}$ Program Studi Ilmu Keperawatan, Universitas Wiararaja \\ ${ }^{3)}$ Program Studi DIII Kebidanan, Universitas Wiararaja \\ Email : zakiyahyasin@yahoo.co.id ${ }^{1)}$ \\ Email : nailiy.huzaimah@wiraraja.ac.id ${ }^{2)}$ \\ Email : Kura_15587@yahoo.com ${ }^{3)}$
}

\begin{abstract}
Tunggak Jati Hamlet is one of the hamlets in Pamolokan Village located in the district.Sumenep City, a hamlet that has a fairly dense population. Communities who in fact have secondary education certainly need better knowledge of Basic Immunization, through the Village PKK provided Posyandu with the hope that the children in Tunggak Jati hamlet will get Complete Basic Immunization, but over time, many Tunggak Jati Hamlet communities do not know the importance and benefits of Complete Basic Immunization, in addition to the lack of the closest form of Posyandu socialization to the public about the importance of complete basic immunization in children under five is also a problem in the provision of Complete Basic Immunization.

With the counseling about the Importance of Providing Complete Basic Immunization in Toddlers, it is expected that posyandu participants can do a healthy lifestyle and other precautions that will occur to provide complete basic immunization to their toddlers.

Through this counseling it is expected:

1. Realization of public knowledge about the importance of providing complete basic immunization in toddlers at the Posyandu in Pamolokan village, Sumenep City District..

2. The creation of a healthy environment in Pamolokan Village, Sumenep City District..

3. The active role of community leaders and family members in participating in improving public health in their environment, especially regarding the Importance of Complete Basic Immunization in Toddlers at the Posyandu in Pamolokan Village, Kota Subdistrict.
\end{abstract}

Keywords: Complete basic immunization, toddlers, Posyandu

\section{PENDAHULUAN}

Kegiatan imunisasi merupakan salah satu kegiatan yang menjadi prioritas kementrian kesehatan, sebagai salah satu bentuk nyata komitmen pemerintah untuk mencapai Milenium Development Goals (MDGs) khususnya untu menurunkan angka kematian pada anak. (Kemenkes, 2012). Program imunisasi dasar, Lima Imunisasi Dasar Lengkap (LIDL), yang dicanangkan oleh pemerintah pada bayi meliputi 1 dosis BCG, 3 dosis DPT, 4 dosis Polio, 4 dosis Hepatitis B, dan 1 dosis campak. Depkes, 2007).

Setiap tahun diseluruh dunia, lebih dari 1,4 juta anak meninggal karena berbagai penyakit yang sesungguhnya masih dapat dicegah dengan imunisasi, hal ini dikarenakan kurangnya dukungan keluarga terhadap praktik pemberian imunisasi. Anak-anak usia muda yang bersekolah dan orang dewasa sama-sama memiliki resiko tinggi terserang penyakit menular yang mematikan seperti difteri, tetanus, hepatitis B, influenza, thypoid, radang selaput otak, radang paru-paru, dan masih banyak lagi (Kemenkes, 2012).

WHO menyatakan bahwa upaya imunisasi sampai tahun 2011 telah mampu melindungi hingga dua sampai tiga juta kematian pada semua kelompok umur dari penyakit menular seperti difteri, tetanus, pertusis, dan campak. Pada kenyataannya, 
jumlah balita yang belum mendapatkan imunisasi masih tergolong sangat banyak, dimana sebanyak 22,4 juta jiwa balita belum mendapatkan imunisasi dasar lengkap pada tahun 2011 jika dibandingkan dengan pencapaian pada tahun 2010 yakni sebesar 21,1 jiwa balita.

Faktor-faktor yang mempengaruhi cakupan imunisasi pada suatu daerah baik itu dari masyarakat maupun petugas kesehatan yang memberikan pelayanan imunisasi misalnyatingkat pendidikan ibu, pekerjaan ibu, tingkat pengetahuan ibu, pendapatan atau penghasilan, pelayanan petugas kesehatan, jarak pelayanan kesehatan, sarana dan prasarana kesehatan, kepercayaan, usia ibu, sikap, dan dukungan keluarga (Suparyanto, 2011). Berkembangnya isu tentang efek samping imunisasi yang menyebabkan demam, kejang, bengkak disekitar area suntikan, hingga autis menyebabkan banyak ibu enggan mengimunisasikan bayinya. Padahal, dengan imunisasi bayi akan terbebas dari beberapa penyakit mematikan seperti pneumonia, diare, dan tetanus. (Aziz. 2005). Hal tersebut menyebabkan kurangnya dukungan keluarga pada praktik pemberian imunisasi.

Dusun Tunggak Jati Desa Pamolokan memiliki PKK yang salah satunya bergerak dibidang POSYANDU Balita. Di dusun ini banyak masyarakat yang belum mengetahui pentingnya Imunisasi Dasar Lengkap sehingga banyak balita di dusun Tunggak Jati Desa Pamolokan ini yang tidak mendapatkan Imunisasi Dasar Lengkap. Dukungan keluarga yang kurang dalam pemberian Imunisasi Dasar masih perlu disosialisasikan lebih lanjut dengan harapan masyarakat di dusun Tunggak Jati Desa Pamolokan sadar akan pentingnya Imunisasi Dasar Lengkap. Cakupan imunisasi yang belum mencapai target dapat menyebabkan angka morbiditas dan mortalitas bayi dan balita tetap tinggi. Resiko untuk terserang penyakit menular seperti difteri, tetanus, hepatitis B, influenza, thypoid, radang selaput otak, radang paru-paru, juga akan tetap tinggi. Upaya yang perlu dilakukan untuk mengatasi masalah tersebut adalah dengan memberikan edukasi kesehatan tentang manfaat imunisasi kepada ibu dan juga keluarganya, karena peran dari keduanya sangatlah penting untuk meningkatkan cakupan imunisasi desa di Indonesia.

\section{KERANGKA PENYELESAIAN MASALAH}

Rangkaian kegiatan yang direncanakan untuk Program Pemberdayaan sebagai berikut:

a. Sosialisasi

Sosialisasi dilakukan setelah adanya kepastian dari LPPM Universitas Wiraraja Sumenep tentang kegiatan ini dan dimaksudkan untuk melihat kesiapan lokasi dan sasaran atau mitra sebagai potret awal daerah kegiatan.

b. Penyusunan Materi

Materi penyuluhan di buat dalam dua bentuk yang pertama yaitu dalam bentul liflet dan yang kedua dalam bentuk power point.

c. Penyiapan sarana dan prasarana Penyuluhan

Sarana dan prasarana yang pelu dipersiapkan pada kegiatan ini meliputi;
(1) Perlengkapan dan bahan Penyuluhan;
(2) Tata ruang/ lay out tempat penyuluhan.

d. Pelaksanaan Penyuluhan

Pada tahap ini peserta penyuluhan akan diberikan pengetahuan tentang Pentingnya imunisasi bagi balita. Peserta yang terlibat pada kegiatan ini adalah masyarakat sekitar Desa Pamolokan Sumenep.

e. Pelaporan Akhir

Laporan akhir merupakan laporan dari seluruh rangkaian kegiatan sebagai wujud pertanggungjawaban secara administratif dari tim pelaksana kepada LPPM Universitas Wiraraja Sumenep. Kegiatan membutuhkan waktu selama enam bulan. 


\section{HASIL KEGIATAN}

Hasil kegiatan penyuluhan di Desa Pamolokan diikuti oleh seluruh masyarakat sebanyak 18 orang dimana berdasarkan kegiatan yang telah dilakukan dalam bentuk ceramah terdapat beberapa hasil evaluasi kegiatan diantaranya:

a. Evaluasi Struktur

(1) Ketua PKK Rt. 003 Rw. 001 Desa Pamolokan dapat bekerja sama dengan baik dan kooperatif dibuktikan dengan dalam persiapan kegiatan dengan ikut serta menyiapkan atau membuat setting tempat penyuluhan.

(2) Ketua PKK Rt. 003 Rw. 001 Desa Pamolokan Kecamatan Kota tampak antusias menerima kunjungan dari tim PKM yaitu dosen Prodi S1 Keperawatan Universitas Wiraraja Sumenep.

b. Evaluasi Proses

(1) Pelaksanaan penyuluhan kesehatan terlihat aktif diikuti masyarakat dilingkungan Desa Pamolokan Kecamatan Kota yang mayoritas diikuti oleh masyarakat di Dusun Tunggak Jati Desa Pamolokan Kecamatan Kota, dimana peserta terlihat aktif dalam berdiskusi serta mengikuti pelayanan kesehatan dengan konsultasi masalah kesehatan bagi dirinya dan dan keluarga.

(2) Peserta kegiatan dapat mengerti tentang Pentingnya Pemberian Imunisasi Dasar Lengkap Pada Anak Balita dibuktikan dengan para peserta dapat menjelaskan tentang Pentingnya Pemberian Imunisasi Dasar Lengkap Pada Anak Balita.

c. Evaluasi Hasil

(1) Peserta kegiatan dapat mengerti dan memahami tentang Pentingnya Pemberian Imunisasi Dasar Lengkap Pada Anak Balita.

d. Keberlanjutan
Bagi Masyarakat dilingkungan Desa Pamolokan Kecamatan Kota perlunya meningkatkan tingkat pengetahuan masyarakat sehingga dapat meningkatkan pengetahuan masyarakat pada umumnya, dan dapat memberikan informasi khusus tentang Pentingnya Pemberian Imunisasi Dasar Lengkap Pada Anak Balita, sehingga dapat memberikan manfaat kesehatan masyarakat secara konprehensif.

\section{Faktor Pendorong}

Dalam pengabdian ini, terdapat faktor pendorong atau pendukung dalam kegiatan pengabdian ini, diantaranya:

a. Peran serta mitra dalam kegiatan Pengabdian Kepada Masyarakat cukup aktif di buktikan sejak awal sosialisasi, Ketua PKK Desa Pamolokan Kecamatan Kota mendukung kegiatan tersebut, dan kegiatan PKM dapat berjalan dengan lancar. Kegiatan PKM di tempatkan di Posyandu Dusun Tunggak Jati Desa Pamolokan Kecamatan Kota dengan persiapan fasilitas kegiatan dapat di support langsung dengan dilakukan secara gotong royong.

b. Dalam Pelaksanaan PKM peran mitra sangat mendukung dimana mitra kegiatan adalah Ketua PKK Desa Pamolokan Kecamatan Kota sehingga dalam kegiatan tersebut mitra kegiatan berpengaruh langsung terhadap masyarakat sehingga acara tersebut berjalan dengan lancar.

\section{Faktor Penghambat}

Selain faktor pendukung atau pendorang, terdapat pula faktor penghambat dalam kegiatan pengabdian ini, diantaranya adalah:

a. Masyarakat masih belum paham betul begitu pentingnya waktu, sehingga dari sebagian peserta masih ada yang terlambat datang pada saat sosialisasi.

b. Masih ada masyarakat yang Acuh Tak acuh ketika sosialisasi. Namun panitia 
langsung menegur dengan sopan peserta sehingga bisa di atasi.

\section{Catatan Pembahasan}

Berdasarkan hasil kegiatan penyuluhan tentang "Pentingnya Pemberian Imunisasi Dasar Lengkap Pada Anak Balita Di Posyandu Desa Pamolokan Kecamatan Kota Sumenep" berdampak baik khusunya bagi masyarakat yang memiliki bayi, dimana Imunisasi memiliki tujuan untuk terhindar dari penyakit-penyakit yang menyerang bayi.

\begin{tabular}{|c|c|c|c|}
\hline No & $\begin{array}{l}\text { Kegiatan } \\
\text { Penyuluh }\end{array}$ & $\begin{array}{l}\text { Respon } \\
\text { Peserta }\end{array}$ & $\begin{array}{l}\text { Wa } \\
\text { ktu }\end{array}$ \\
\hline 1 & 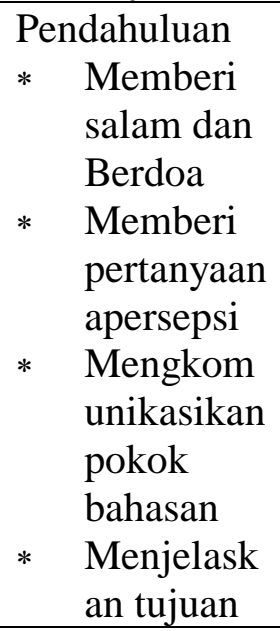 & $\begin{array}{ll}* & \text { Menjaw } \\
& \text { ab } \\
& \text { salam } \\
* & \text { Membe } \\
& \text { ri salam } \\
* & \text { Menyi } \\
& \text { mak } \\
* & \text { Menyi } \\
& \text { mak }\end{array}$ & $\begin{array}{l}10 \\
\mathrm{mnt}\end{array}$ \\
\hline 2 & $\begin{array}{l}\text { Kegiatan Inti } \\
\text { * } \\
\text { Memberik } \\
\text { an } \\
\text { penjelasan } \\
\text { tentang } \\
\text { pentingnya } \\
\text { imunisasi } \\
\text { dasar } \\
\text { lengkap } \\
\text { * Memberik } \\
\text { an } \\
\text { kesempata } \\
\text { n warga } \\
\text { untuk } \\
\text { bertanya } \\
\text { Menjawab } \\
\text { pertanyaan } \\
\text { warga }\end{array}$ & 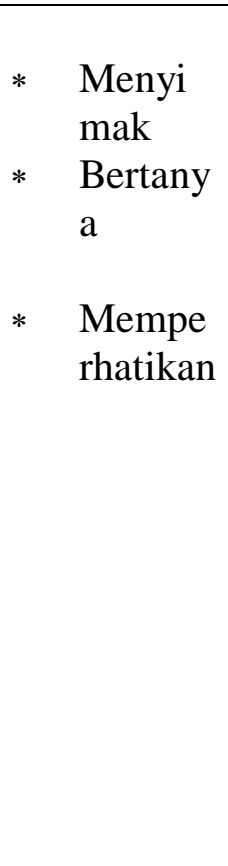 & $\begin{array}{l}25 \\
\mathrm{mnt}\end{array}$ \\
\hline 3 & \begin{tabular}{lc}
\multicolumn{2}{l}{ Penutup } \\
$* \quad$ Menyimpu \\
lkan materi
\end{tabular} & $\begin{array}{l}\text { * Mempe } \\
\text { rhatikan }\end{array}$ & $\begin{array}{l}5 \\
\mathrm{mnt}\end{array}$ \\
\hline
\end{tabular}

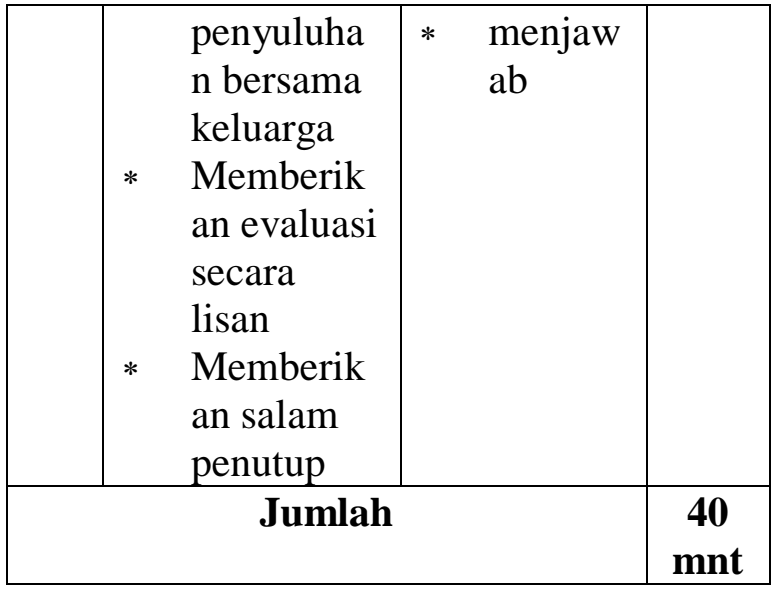

\section{KESIMPULAN}

Penyuluhan Kesehatan tentang Pentingnya Pemberian Imunisasi Dasar Lengkap Pada Anak Balita Di Rt. 03 Rw. 01 Desa Pamolokan Kecamatan Kota Sumenep berjalan dengan baik, sehingga berdasarkan hasil evaluasi masyarakat sangat antusias mengikuti penyuluhan tersebut dan sangat bermanfaat bagi masyarakat khususnya ibu yang yang memiliki balita.

Kegiatan Penyuluhan kesehatan tersebut berdampak positif bagi masyarakan di Lingkungan Desa Pamolokan Kecamatan Kota Sumenep sehingga dapat mewujudkan peningkatan pengetahuan masyarakat tentang Pentingnya Pemberian Imunisasi Dasar Lengkap Pada Anak Balita Desa Pamolokan Kecamatan Kota Sumenep, dan dapat menciptakan lingkungan sehat di Desa Pamolokan Kecamatan Kota Sumenep.

\section{SARAN}

a. Petugas kesehatan Puskesmas agar selalu memberikan informasi pada ibu yang memiliki balita tentang Pentingnya Pemberian Imunisasi Dasar Lengkap Pada Anak Balita serta memberi informasi kepada keluarga untuk mendukung menemani untuk selalu melakukan kontrol secara rutin pada masyarakat, serta tingkatkan komunikasi terapeutik kepada masyarakat.

b. Dapat menjadi tambahan informasi mengenai pentingnya upaya promotif, preventif, kuratif Pentingnya 
Pemberian Imunisasi Dasar Lengkap

Pada Anak Balita serta selalu melakukan kontrol kesehatan di pelayanan kesehatan.

\section{DAFTAR PUSTAKA}

Depkes, RI. (2007). Profil Kesehatan Indonesia. Jakarta : Departemen Kesehatan RI

Hidayat, Alimul Aziz. (2005). Pengantar Ilmu Keperawatan Anak 1. Jakarta : Salemba Medika

Kemenkes, RI. (2012). Pusat Data dan Informasi Profil Kesehatan Indonesia 2012. Jakarta : Kementrian Kesehatan RI Lampiran 17

Suparyanto. 2011. Konsep dan peran ibu dalam keluarga. http://Suparyanto.blogspot.com. Di unduh tanggal 20 September 2018. 